\title{
Optymalizacja strategii wzorcowania w analizie zawartości lekkich węglowodorów w próbkach stałych metodą chromatografii gazowej z ekstrakcją do fazy nadpowierzchniowej (HS-GC-FID)
}

\begin{abstract}
W artykule opisano proces optymalizacji strategii wzorcowania w analizach lekkich węglowodorów, takich jak węglowodory benzynowe i węglowodory aromatyczne z grupy BTEX, w próbkach stałych. Optymalizacja polegała na wykonaniu szeregu analiz próbek gleb zanieczyszczonych w laboratorium, z wykorzystaniem metody chromatografii gazowej z ekstrakcją do fazy nadpowierzchniowej, i zastosowaniu dwóch strategii wzorcowania (ekstrapolacyjnej i interpolacyjnej). Badania miały na celu dobór odpowiedniej strategii wzorcowania, w zależności od typu wykonywanych analiz. W przypadku oznaczania węglowodorów benzynowych lepsza okazała się być metoda interpolacyjna, natomiast dla grupy węglowodorów aromatycznych zadowalające wyniki uzyskano, wykorzystując metodę ekstrapolacyjną z dodatkiem wzorca o stężeniu nie wyższym niż zawartość zanieczyszczenia w badanej próbce.
\end{abstract}

Słowa kluczowe: wzorcowanie, metoda interpolacyjna, metoda ekstrapolacyjna, lekkie węglowodory, chromatografia gazowa, headspace, próbki stałe.

\section{Optimization calibration strategy in the content analysis of light hydrocarbons in solid samples by gas chromatography and headspace extraction (HS-GC-FID)}

\begin{abstract}
The article describes the process of optimizing the strategy calibration analyzes of light hydrocarbons such as $\mathrm{C}_{6}-\mathrm{C}_{12}$ and aromatic hydrocarbons from a group of BTEX in solid samples. Optimization included a series of studies in laboratory contaminated soil samples using gas chromatography, and headspace extraction using two strategies of calibration: extrapolation and interpolation. The purpose of the studies was to choose the right strategy for calibration, depending on the type of analyzes. For the determination of $\mathrm{C}_{6}-\mathrm{C}_{12}$ hydrocarbons the better method has proved to be the interpolation method, whereas from the group of aromatic hydrocarbons, better results were obtained using the extrapolation method, but the concentration of standard addition should not be higher than the contamination in a real sample.
\end{abstract}

Key words: calibration, extrapolation, methods interpolation, light hydrocarbons, gas chromatography, head-space, solid samples.

\section{Wstęp}

Wykonywanie analiz pod kątem zawartości węglowodorów ropopochodnych w próbkach stałych, ze względu na ich niejednorodność i złożoną matrycę, często przysparza wielu problemów. Dlatego też niezmiernie istotny jest etap wzorcowania analizy, przeprowadzony tak, aby ograniczyć wpływ matrycy na otrzymywane wyniki. W analizie próbek środowiskowych wyróżniamy dwa główne typy prowadzenia wzor- cowania: jest to metoda interpolacyjna oraz ekstrapolacyjna. W obu wymienionych metodach wynik analityczny wyznacza się za pomocą uzyskanej krzywej wzorcowej, biorąc pod uwagę sygnał zmierzony dla próbki, jednak sposób konstruowania krzywej wzorcowej jest inny. W metodzie interpolacyjnej wynik analityczny określany jest na podstawie krzywej wzorcowej w obszarze wyznaczonym doświadczalnie, 
czyli sygnał analityczny zmierzony dla badanej próbki mieści się w obrębie sygnałów wzorców. Natomiast w metodzie ekstrapolacyjnej dokonuje się pomiaru sygnału dla samej próbki oraz dla próbek z dodatkiem lub dodatkami wzorca. Krzywa wzorcowa skonstruowana na tej podstawie obejmuje ograniczony zakres stężeń: od stężenia analitu w próbce do sumarycznego stężenia analitu w próbce i największym dodatku wzorca. Wyznaczenie wyniku jest więc możliwe tylko poprzez ekstrapolację tej krzywej do przecięcia z osią stężeń. Różny sposób określania wyniku analitycznego prowadzi do tego, że metoda ekstrapolacyjna powinna być bardziej odporna na występujące efekty interferencyjne. Metoda ta nie jest jednak pozbawiona istotnych wad, jedną z nich jest konieczność wykonania osobnego wzorcowania dla każdej analizowanej próbki. Natomiast w przypadku metody interpolacyjnej jedna krzywa wzorcowa może być stosowana do wyznaczania wyniku analitycznego serii próbek. Podczas badań oceniono możliwość użycia wzorcowania interpola- cyjnego i ekstrapolacyjnego podczas oznaczania zawartości węglowodorów benzynowych oraz węglowodorów aromatycznych z grupy BTEX w próbkach stałych.

Dobór odpowiedniej metody wzorcowania jest niezwykle ważny także z punktu widzenia możliwości przeprowadzenia rekultywacji skażonej gleby/odpadu. Aby móc monitorować procesy bioremediacji i oceniać ich efektywność, niezbędnym elementem jest wykorzystanie odpowiedniej metody chromatograficznej - pozwalającej na oznaczenie zanieczyszczeń ropopochodnych z podziałem na poszczególne grupy węglowodorów [2]. Natomiast w przypadku braku możliwości poddania gleby procesom rekultywacji należy ją traktować jako odpad. W takiej sytuacji bardzo ważnym elementem jest właściwa klasyfikacja i ocena odpadu, która pozwoli na wskazanie, w jaki sposób może być on składowany. Aby móc przeprowadzić taką ocenę, konieczne jest przeprowadzenie szeregu badań, w tym między innymi węglowodorów ropopochodnych [1].

\section{Metodyka badań}

Oznaczanie lekkich węglowodorów, takich jak węglowodory benzynowe czy jednopierścieniowe węglowodory aromatyczne, prowadzone jest najczęściej metodami chromatografii gazowej z wykorzystaniem detekcji płomieniowo-jonizacyjnej (GC-FID) lub detekcji masowej (GC-MS). W opisywanych badaniach podczas oznaczania węglowodorów benzynowych oraz węglowodorów aromatycznych wykorzystano metodę GC-FID. W obu tych przypadkach rozdział analitów następował na kolumnie chromatograficznej ZB-624 w zoptymalizowanym programie temperaturowym pozwalającym na oznaczenie w jednej analizie obu grup związków. Istotnym elementem $w$ analizach ilościowych lekkich węglowodorów w próbkach stałych jest proces ekstrakcji analitu z próbki, pozwalający na wykonanie oznaczenia metodą chromatografii gazowej. Przyjmuje się, że w przypadku lekkich analitów (np. węglowodorów benzynowych czy BTEX) korzystne jest stosowanie ekstrakcji bezrozpuszczalnikowych, np. ekstrakcji do fazy nadpowierzchniowej (headspace). Technika ekstrakcji do fazy nadpowierzchniowej polega na analizowaniu par będących w równowadze z ciekłą lub stałą próbką zamkniętą w szczelnej fiolce. W opisywanych badaniach zastosowano najprostszą odmianę techniki headspace - tak zwaną statyczną technikę headspace. Polega ona na tym, że odmierzoną masę próbki gleby, po zamknięciu w szczelnej fiolce, umieszcza się w termostacie, który ogrzewa próbkę w zadanych warunkach temperaturowych przez czas niezbędny do osiągnięcia równowagi międzyfazowej. Po ustaleniu równowagi pomiędzy fazą stałą a fazą gazową, pobierana jest określona objętość par, którą następnie poddaje się analizie chromatograficznej. Podczas prowadzenia ekstrakcji do fazy nadpowierzchniowej niezmiernie istotne jest utrzymanie stałych warunków w trakcie termostatowania próbek.

\section{Wybór strategii wzorcowania dla węglowodorów benzynowych}

Pierwszym krokiem w doborze odpowiedniej strategii wzorcowania było wykonanie interpolacyjnej krzywej wzorcowej w zakresie stężeń od 1,5 do $950 \mathrm{mg} / \mathrm{kg}$, wykorzystując do tego celu glebę niezawierającą węglowodorów. Ze względu na szeroki zakres analizowanych stężeń, krzywą wzorcową podzielono na dwa zakresy: pierwszy od 1 do $100 \mathrm{mg} / \mathrm{kg}$, drugi od 100 do $950 \mathrm{mg} / \mathrm{kg}$. Przebieg krzywych wzorcowych przedstawiono na rysunkach 1 i 2 .

Obie krzywe przedstawione na rysunkach 1 i 2 charakteryzują się dobrym dopasowaniem liniowym, o czym świad- czą wysokie wartości współczynnika $r$, który w przypadku pierwszej krzywej wynosi 0,998, a dla krzywej przedstawionej na rysunku 2 osiąga wartość 0,999 .

W celu oceny, która strategia wzorcowania pozwoli na uzyskanie lepszych wyników podczas oznaczania zawartości węglowodorów benzynowych w próbkach stałych, skażono glebę tak, aby otrzymać próbki gleby o zawartości węglowodorów benzynowych na czterech poziomach stężeń:

- poziom I - próbka $\mathrm{A}_{0}-810 \mathrm{mg} / \mathrm{kg}$,

- poziom II - próbka $\mathrm{B}_{0}-609 \mathrm{mg} / \mathrm{kg}$, 
- poziom III - próbka $\mathrm{C}_{0}-60,9 \mathrm{mg} / \mathrm{kg}$,

- poziom IV - próbka $\mathrm{D}_{0}-1,2 \mathrm{mg} / \mathrm{kg}$.

Do przygotowania skażonych próbek gleby wykorzystano glebę niezawierającą węglowodorów, inną niż ta, której użyto do wykonania wzorcowania interpolacyjnego. Tak przygotowane próbki gleby posłużyły do sprawdzenia, która ze strategii wzorcowania: interpolacyjna czy ekstrapolacyjna, jest korzystniejsza przy oznaczaniu węglowodorów benzynowych w próbkach stałych. W przypadku metody interpolacyjnej do wyznaczenia wyniku analitycznego posłużyły krzywe wzorcowe wykonane z użyciem benzyny jako wzorca, przedstawione na rysunkach 1 i 2 . Natomiast podczas metody ekstrapolacyjnej do skażonych próbek gleby wprowadzono dodatki wzorca na czterech różnych poziomach stężeń uzyskanych według następującego schematu:
- $\mathrm{A}_{0}$

- $\mathrm{A}_{1}=\mathrm{A}+1 / 4 \mathrm{C}_{\mathrm{A} 0}$

- $\mathrm{A}_{2}=\mathrm{A}+1 / 2 \mathrm{C}_{\mathrm{A} 0}$

- $\mathrm{A}_{3}=\mathrm{A}+\mathrm{C}_{\mathrm{A} 0}$

- $\mathrm{A}_{4}=\mathrm{A}+2 \mathrm{C}_{\mathrm{A} 0}$

- $\mathrm{C}_{0}$

- $\mathrm{C}_{1}=\mathrm{C}+1 / 2 \mathrm{C}_{\mathrm{C} 0}$

- $\mathrm{C}_{2}=\mathrm{C}+\mathrm{C}_{\mathrm{C} 0}$

- $\mathrm{C}_{3}=\mathrm{C}+2 \mathrm{C}_{\mathrm{C} 0}$

- $\mathrm{C}_{4}=\mathrm{C}+4 \mathrm{C}_{\mathrm{C} 0}$
- $\mathrm{B}_{0}$

- $\mathrm{B}_{1}=\mathrm{B}+1 / 4 \mathrm{C}_{\mathrm{B} 0}$

- $\mathrm{B}_{2}=\mathrm{B}+1 / 2 \mathrm{C}_{\mathrm{B} 0}$

- $\mathrm{B}_{3}=\mathrm{B}+\mathrm{C}_{\mathrm{B} 0}$

- $\mathrm{B}_{4}=\mathrm{B}+2 \mathrm{C}_{\mathrm{B} 0}$

- $\mathrm{D}_{0}$

- $\mathrm{D}_{1}=\mathrm{D}+1 / 2 \mathrm{C}_{\mathrm{D} 0}$

- $\mathrm{D}_{2}=\mathrm{D}+\mathrm{C}_{\mathrm{D} 0}$

- $\mathrm{D}_{3}=\mathrm{D}+2 \mathrm{C}_{\mathrm{D} 0}$

- $\mathrm{D}_{4}=\mathrm{D}+4 \mathrm{C}_{\mathrm{D} 0}$ gdzie:

$\mathrm{A}_{0}, \mathrm{~B}_{0}, \mathrm{C}_{0}, \mathrm{D}_{0}$ - próbki jednostkowe (10 g) skażonej gleby bez dodatku wzorca,

$\mathrm{A}_{1-4}, \mathrm{~B}_{1-4}, \mathrm{C}_{1-4}, \mathrm{D}_{1-4}$ - próbki jednostkowe skażonej gleby z dodatkami wzorca na różnym poziomie stężeń,

$\mathrm{C}_{\mathrm{A} 0}, \mathrm{C}_{\mathrm{B} 0}, \mathrm{C}_{\mathrm{C} 0}, \mathrm{C}_{\mathrm{D} 0}$ - rzeczywiste stężenie benzyny w glebie poddanej analizie $[\mathrm{mg} / \mathrm{kg}]$.

Takie postepowanie w metodzie ekstrapolacyjnej pozwoliło na ocenę, jaki poziom dodatku wzorca w tej technice jest najkorzystniejszy.

Wyniki analiz gleb z wykorzystaniem metody interpolacyjnej przedstawiono w tablicy 1, natomiast ekstrapolacyjnej - w tablicy 2. Błąd względny wyraża iloraz błędu bez-

Tablica 1. Stężenie benzyny w skażonych glebach uzyskane z wykorzystaniem metody interpolacyjnej

\begin{tabular}{|c|c|c|c|}
\hline \multicolumn{2}{|c|}{$\begin{array}{c}\text { Wartość oczekiwana } \\
{[\mathrm{mg} / \mathrm{kg}]}\end{array}$} & $\begin{array}{c}\text { Wynik oznaczenia } \\
{[\mathrm{mg} / \mathrm{kg}]}\end{array}$ & $\begin{array}{c}\text { Błąd względny } \\
{[\%]}\end{array}$ \\
\hline $\mathrm{A}_{0}$ & 809,7 & $811,5 \pm 121,7$ & 0,2 \\
\hline $\mathrm{B}_{0}$ & 609,2 & $652,9 \pm 98,0$ & 7,2 \\
\hline $\mathrm{C}_{0}$ & 60,9 & $65,7 \pm 13,1$ & 7,9 \\
\hline $\mathrm{D}_{0}$ & 1,2 & $4,7 \pm 1,2$ & 292,0 \\
\hline
\end{tabular}

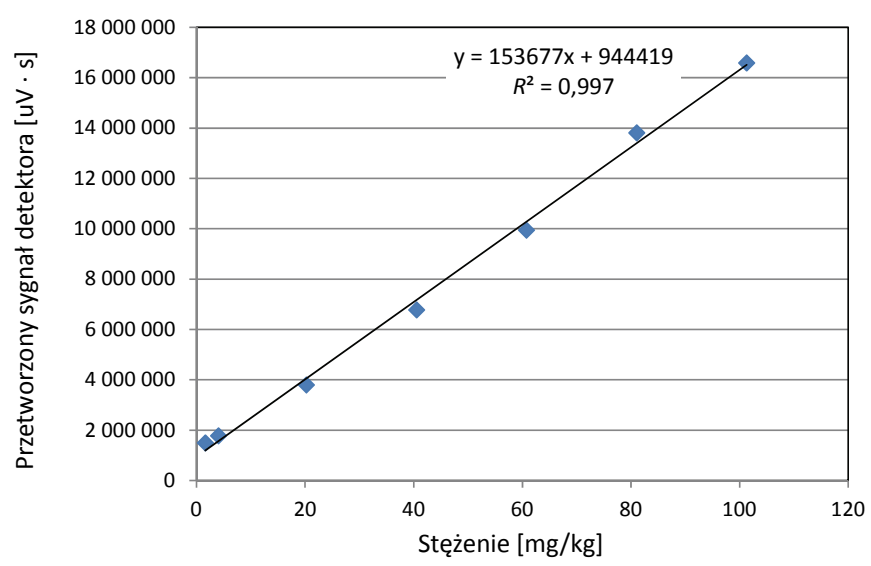

Rys. 1. Krzywa wzorcowa dla węglowodorów benzynowych - zakres stężeń od 1 do $100 \mathrm{mg} / \mathrm{kg}$

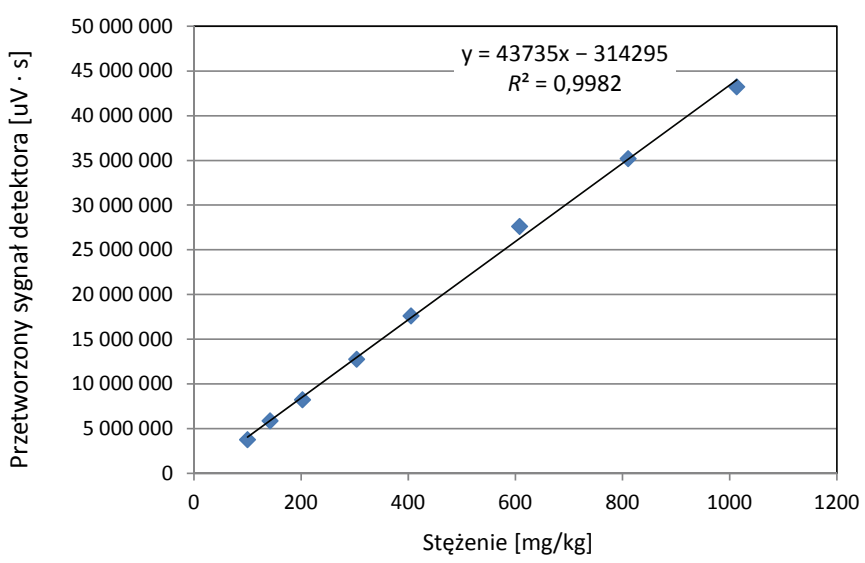

Rys. 2. Krzywa wzorcowa dla węglowodorów benzynowych - zakres stężeń od 100 do $950 \mathrm{mg} / \mathrm{kg}$

Tablica 2. Wyniki analiz przeprowadzonych metodą ekstrapolacyjną

\begin{tabular}{|c|c|c|c|}
\hline & $\begin{array}{l}\text { Symbol } \\
\text { dodatku } \\
\text { wzorca }\end{array}$ & $\begin{array}{c}\text { Wynik oznaczenia } \\
\text { w próbce bez } \\
\text { dodatku wzorca } \\
{[\mathrm{mg} / \mathrm{kg}]}\end{array}$ & $\begin{array}{c}\text { Błąd } \\
\text { względny } \\
{[\%]}\end{array}$ \\
\hline \multirow{4}{*}{$\begin{array}{c}\text { Gleba A }_{0} \\
(809,7 \mathrm{mg} / \mathrm{kg})\end{array}$} & $\mathrm{A}_{1}$ & $49,2 \pm 12,3$ & $-93,90$ \\
\hline & $\mathrm{A}_{2}$ & $75,6 \pm 15,1$ & $-90,70$ \\
\hline & $\mathrm{A}_{3}$ & $112,5 \pm 22,5$ & $-86,10$ \\
\hline & $\mathrm{A}_{4}$ & $133,7 \pm 26,7$ & $-83,50$ \\
\hline \multirow{4}{*}{$\begin{array}{c}\text { Gleba B } \\
(609,2 \mathrm{mg} / \mathrm{kg})\end{array}$} & $\mathrm{B}_{1}$ & $695,3 \pm 104,3$ & 14,10 \\
\hline & $\mathrm{B}_{2}$ & $925,7 \pm 138,8$ & 52,00 \\
\hline & $\mathrm{B}_{3}$ & $618,5 \pm 92,8$ & 1,50 \\
\hline & $\mathrm{B}_{4}$ & $725,1 \pm 108,8$ & 19,00 \\
\hline \multirow{4}{*}{$\begin{array}{c}\text { Gleba C }_{0} \\
(60,92 \mathrm{mg} / \mathrm{kg})\end{array}$} & $\mathrm{C}_{1}$ & $95,13 \pm 19,0$ & 56,15 \\
\hline & $\mathrm{C}_{2}$ & $60,10 \pm 12,0$ & 1,35 \\
\hline & $\mathrm{C}_{3}$ & $66,02 \pm 13,2$ & 8,37 \\
\hline & $\mathrm{C}_{4}$ & $67,27 \pm 13,4$ & 10,43 \\
\hline \multirow{4}{*}{$\begin{array}{c}\text { Gleba } D_{0} \\
(1,22 \mathrm{mg} / \mathrm{kg})\end{array}$} & $\mathrm{D}_{1}$ & $4,2 \pm 1,1$ & 244,30 \\
\hline & $\mathrm{D}_{2}$ & $7,9 \pm 2,0$ & 546,70 \\
\hline & $\mathrm{D}_{3}$ & $7,3 \pm 1,8$ & 494,80 \\
\hline & $\mathrm{D}_{4}$ & $7,8 \pm 1,9$ & 541,50 \\
\hline
\end{tabular}


względnego (różnica między wartością rzeczywistą a zmierzoną) i wartości oczekiwanej, wyrażony w procentach.

Porównując strategię ekstrapolacyjną i interpolacyjną, należy zauważyć, że niezależnie od zastosowanej strategii wzorcowania w próbkach o najniższej zawartości benzyny (gleba $\mathrm{D}_{0}$ ) koncentracja węglowodorów $\mathrm{C}_{6}-\mathrm{C}_{12}$ została oznaczona z nieakceptowalnie dużym błędem. Należy jednak pamiętać, że zawartość węglowodorów benzynowych na tym poziomie jest graniczna dla gleb z terenów chronionych oraz wierzchniej warstwy gleby na terenach rolniczych [3]. W laboratoriach badających próbki gleby z terenów górnictwa nafty i gazu oraz odpady oznaczenie tak niskich zawartości węglowodorów w próbkach nie jest konieczne. Dla pozostałych poziomów skażeń gleby lepsze wyniki otrzymano metodą interpolacyjną. W przypadku metody ekstrapolacyjnej uzyskanie prawidłowych wyników wymagało precy- zyjnego dobrania ilości substancji wzorcowej wprowadzanej w dodatku wzorca. Otrzymane wyniki pokazały, że ilość substancji wzorcowej wprowadzonej do próbki jako dodatek wzorca powinna być większa niż spodziewana zawartość analitu. Dodatkowo w metodzie ekstrapolacyjnej zauważyć można problemy z oznaczeniem wysokich stężeń benzyny. Na przykładzie gleby $\mathrm{A}_{0}$ pokazano, że efektywne przeprowadzenie dużej ilości węglowodorów do fazy nadpowierzchniowej jest trudne i w przypadku tego typu próbek należałoby stosować mniejsze naważki gleby wykorzystywane podczas wykonywania ekstrakcji metodą headspa$c e$. Jednak w przypadku próbek niejednorodnych jest to ryzykowne rozwiązanie, które w celu uzyskania wiarygodnego wyniku wymagałoby poddania analizie od $3 \div 5$ próbek oraz próbek z dodatkami wzorca, co generować będzie wysokie koszty analizy pojedynczej próbki.

\section{Wybór strategii wzorcowania dla węglowodorów aromatycznych BTEX}

W celu sprawdzenia, która ze strategii wzorcowania pozwoli na uzyskanie dokładniejszych wyników analizy zawartości węglowodorów BTEX w próbkach gleby, podobnie jak w przypadku poprzedniej grupy węglowodorów, skażono próbki gleby węglowodorami z grupy BTEX, uzyskując następujące stężenia węglowodorów aromatycznych w glebach:

- gleba I - próbka $\mathrm{E}_{0}$ :

- benzen $-109,2 \mathrm{mg} / \mathrm{kg}$,

- toluen $-127,0 \mathrm{mg} / \mathrm{kg}$,

- etylobenzen $-90,5 \mathrm{mg} / \mathrm{kg}$,

- o-ksylen $-86,9 \mathrm{mg} / \mathrm{kg}$,

- gleba II - próbka $F_{0}$ :

- benzen $-0,51 \mathrm{mg} / \mathrm{kg}$,

- toluen $-0,82 \mathrm{mg} / \mathrm{kg}$,

- etylobenzen $-0,55 \mathrm{mg} / \mathrm{kg}$,

- o-ksylen $-0,48 \mathrm{mg} / \mathrm{kg}$.

Aby ocenić możliwość stosowania wzorcowania interpolacyjnego, w pierwszym etapie badań wykonano krzywe wzorcowe dla każdego $\mathrm{z}$ węglowodorów BTEX w zakresie stężeń od $0,1 \mathrm{mg} / \mathrm{kg}$ do $200 \mathrm{mg} / \mathrm{kg}$. Wykorzystując uzyskane krzywe, przeprowadzono badania gleb $\left(\mathrm{E}_{0}, \mathrm{~F}_{0}\right)$ skażonych węglowodorami z grupy BTEX, a wyniki przedstawiono w tablicach 3 i 4 . W pierwszej kolejności każdy z węglowodorów wzorcowany był bezpośrednio do krzywej wzorcowej uzyskanej z użyciem danego węglowodoru. Następnie wykonano również wzorcowanie pośrednie, w którym wynik analityczny został wyznaczony na podstawie krzywej uzyskanej dla innego węglowodoru. Podczas wzorcowania pośredniego wykorzystano względny współczynnik odpowiedzi, uwzględniający ilość atomów węgla $\mathrm{w}$ analicie $\mathrm{i}$ wzorcu.
Analizując uzyskane wyniki, można zauważyć, że w przypadku gleby $\mathrm{E}_{0}$ (o wysokim skażeniu) błąd względny dla wzorcowania bezpośredniego wynosi około $30 \%$ - niezależnie

Tablica 3. Wyniki oznaczania węglowodorów BTEX metodą interpolacyjną bezpośrednią i pośrednią $\mathrm{w}$ glebie $\mathrm{E}_{0}$

\begin{tabular}{|c|c|c|}
\hline $\begin{array}{c}\text { Sposób wyznaczenia } \\
\text { wyniku }\end{array}$ & $\begin{array}{c}\text { Wynik oznaczenia } \\
{[\mathrm{mg} / \mathrm{kg}]}\end{array}$ & $\begin{array}{c}\text { Błąd } \\
\text { względny } \\
{[\%]}\end{array}$ \\
\hline \multicolumn{2}{|c|}{ Gleba $\mathrm{E}_{0}-$ benzen (wartość oczekiwana $109,2 \mathrm{mg} / \mathrm{kg}$ ) }
\end{tabular}

\begin{tabular}{|l|c|c|}
\hline Bezpośrednio & $86,5 \pm 17,3$ & 20,8 \\
\hline Pośrednio do toluenu & $76,1 \pm 15,2$ & 30,3 \\
\hline Pośrednio do etylobenzenu & $81,6 \pm 16,3$ & 25,3 \\
\hline Pośrednio do ksylenu & $77,8 \pm 15,6$ & 28,8 \\
\hline \multicolumn{3}{|c|}{ Gleba $E_{0}$ - toluen (wartość oczekiwana 127,0 mg/kg) } \\
\hline Bezpośrednio & $101,8 \pm 15,3$ & 20,0 \\
\hline Pośrednio do benzenu & $86,1 \pm 17,3$ & 32,3 \\
\hline Pośrednio do etylobenzenu & $95,6 \pm 19,1$ & 24,8 \\
\hline Pośrednio do ksylenu & $90,9 \pm 18,2$ & 28,5 \\
\hline \multicolumn{3}{|c|}{ Gleba E - etylobenzen (wartość oczekiwana 90,5 mg/kg) } \\
\hline Bezpośrednio & $127,9 \pm 19,2$ & 41,4 \\
\hline Pośrednio do benzenu & $89,0 \pm 17,8$ & 1,6 \\
\hline Pośrednio do toluenu & $104,0 \pm 15,6$ & 14,9 \\
\hline Pośrednio do ksylenu & $121,3 \pm 18,2$ & 34,0 \\
\hline \multicolumn{3}{|c|}{ Gleba E - ksyleny (wartość oczekiwana 86,9 mg/kg) } \\
\hline Bezpośrednio & $99,7 \pm 19,9$ & 14,7 \\
\hline Pośrednio do benzenu & $125,4 \pm 18,8$ & 44,3 \\
\hline Pośrednio do toluenu & $85,4 \pm 17,1$ & 1,8 \\
\hline Pośrednio do etylobenzenu & $104,7 \pm 15,7$ & 20,5 \\
\hline \multicolumn{2}{|c|}{} \\
\hline
\end{tabular}


Tablica 4. Wyniki oznaczania węglowodorów BTEX metodą interpolacyjną bezpośrednią i pośrednią $\mathrm{W}$ glebie $\mathrm{F}_{0}$

Sposób wyznaczenia wyniku

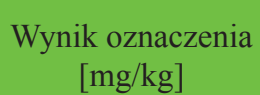

Błąd względny

Gleba $\mathrm{F}_{0}$ - benzen (wartość oczekiwana $0,51 \mathrm{mg} / \mathrm{kg}$ )

\begin{tabular}{|l|l|c|}
\hline Bezpośrednio & $0,47 \pm 0,12$ & 7,2 \\
\hline Pośrednio do toluenu & \multicolumn{2}{|c|}{ otrzymano wynik ujemny } \\
\hline Pośrednio do etylobenzenu & otrzymano wynik ujemny \\
\hline Pośrednio do ksylenu & otrzymano wynik ujemny \\
\hline
\end{tabular}

Gleba $\mathrm{F}_{0}$ - toluen (wartość oczekiwana $0,82 \mathrm{mg} / \mathrm{kg}$ )

\begin{tabular}{|c|c|c|}
\hline Bezpośrednio & \multicolumn{2}{|c|}{ otrzymano wynik ujemny } \\
\hline Pośrednio do benzenu & $0,71 \pm 0,18$ & 11,7 \\
\hline Pośrednio do etylobenzenu & \multicolumn{2}{|c|}{ otrzymano wynik ujemny } \\
\hline Pośrednio do ksylenu & \multicolumn{2}{|c|}{ otrzymano wynik ujemny } \\
\hline \multicolumn{3}{|c|}{ Gleba $\mathrm{F}_{0}$ - etylobenzen (wartość oczekiwana $0,55 \mathrm{mg} / \mathrm{kg}$ ) } \\
\hline Bezpośrednio & \multicolumn{2}{|c|}{ otrzymano wynik ujemny } \\
\hline Pośrednio do benzenu & $0,36 \pm 0,09$ & 33,8 \\
\hline Pośrednio do toluenu & \multicolumn{2}{|c|}{ otrzymano wynik ujemny } \\
\hline Pośrednio do ksylenu & \multicolumn{2}{|c|}{ otrzymano wynik ujemny } \\
\hline \multicolumn{3}{|c|}{ Gleba $\mathrm{F}_{0}$ - ksyleny (wartość oczekiwana 0,48 mg/kg) } \\
\hline Bezpośrednio & \multicolumn{2}{|c|}{ otrzymano wynik ujemny } \\
\hline Pośrednio do benzenu & $0,38 \pm 0,10$ & 20,7 \\
\hline Pośrednio do toluenu & \multicolumn{2}{|c|}{ otrzymano wynik ujemny } \\
\hline Pośrednio do etylobenzenu & \multicolumn{2}{|c|}{ otrzymano wynik ujemny } \\
\hline
\end{tabular}

Tablica 5. Wyniki oznaczania węglowodorów BTEX metodą ekstrapolacyjną $\mathrm{w}$ glebie $\mathrm{E}_{0}$

\begin{tabular}{|c|c|c|c|}
\cline { 2 - 4 } \multicolumn{1}{c|}{} & $\begin{array}{c}\text { Symbol } \\
\text { dodatku } \\
\text { wzorca }\end{array}$ & $\begin{array}{c}\text { Wynik oznaczenia } \\
\text { w próbce bez } \\
\text { dodatku wzorca } \\
{[\mathrm{mg} / \mathrm{kg}]}\end{array}$ & $\begin{array}{c}\text { Błąd } \\
\text { wzgleddny } \\
{[\%]}\end{array}$ \\
\hline \multirow{4}{*}{$\begin{array}{c}\text { Gleba } \mathrm{E}_{0}-\text { benzen } \\
(109,2 \mathrm{mg} / \mathrm{kg})\end{array}$} & $\mathrm{E}_{1}$ & $119,1 \pm 17,9$ & 9,00 \\
\cline { 2 - 4 } & $\mathrm{E}_{2}$ & $127,3 \pm 19,1$ & 16,50 \\
\cline { 2 - 4 } & $\mathrm{E}_{3}$ & $119,3 \pm 17,9$ & 9,18 \\
\cline { 2 - 4 } & $\mathrm{E}_{4}$ & $128,4 \pm 19,3$ & 17,50 \\
\hline \multirow{4}{*}{$\begin{array}{c}\text { Gleba } \mathrm{E}_{0}-\text { toluen } \\
(127,0 \mathrm{mg} / \mathrm{kg})\end{array}$} & $\mathrm{E}_{1}$ & $108,9 \pm 16,3$ & 14,26 \\
\cline { 2 - 4 } & $\mathrm{E}_{2}$ & $128,8 \pm 19,3$ & 1,39 \\
\cline { 2 - 4 } & $\mathrm{E}_{3}$ & $117,7 \pm 17,7$ & 7,36 \\
\cline { 2 - 4 } Gleba $\mathrm{E}_{0}-$ etylobenzen & $\mathrm{E}_{4}$ & $51,0 \pm 10,2$ & 59,85 \\
\hline \multirow{4}{*}{$(90,5 \mathrm{mg} / \mathrm{kg})$} & $\mathrm{E}_{1}$ & $89,9 \pm 18,0$ & 0,65 \\
\cline { 2 - 4 } & $\mathrm{E}_{2}$ & $79,6 \pm 15,9$ & 12,08 \\
\cline { 2 - 4 } & $\mathrm{E}_{3}$ & $78,5 \pm 15,7$ & 13,21 \\
\cline { 2 - 4 } & $\mathrm{E}_{4}$ & $44,3 \pm 11,1$ & 51,08 \\
\hline \multirow{3}{*}{$\begin{array}{c}\text { Gleba } \mathrm{E}_{0}-\mathrm{ksyleny} \\
(86,9 \mathrm{mg} / \mathrm{kg})\end{array}$} & $\mathrm{E}_{1}$ & $85,4 \pm 17,1$ & 1,70 \\
\cline { 2 - 4 } & $\mathrm{E}_{2}$ & $89,2 \pm 17,8$ & 2,59 \\
\cline { 2 - 4 } & $\mathrm{E}_{3}$ & $92,4 \pm 18,5$ & 6,32 \\
\cline { 2 - 4 } & $\mathrm{E}_{4}$ & $81,5 \pm 16,3$ & 6,21 \\
\hline
\end{tabular}

od tego, czy zastosowane zostało wzorcowanie interpolacyjne, czy ekstrapolacyjne. Natomiast dla gleby skażonej węglowodorami aromatycznymi na poziomie nieprzekraczającym $1 \mathrm{mg} / \mathrm{kg}$ (gleba $\mathrm{F}_{0}$ ) w przypadku wzorcowania interpolacyjnego bezpośredniego otrzymano prawidłowy wynik jedynie w przypadku oznaczania benzenu. Dla pozostałych składników uzyskane wyniki oznaczenia z wykorzystaniem wzorcowania interpolacyjnego bezpośredniego były ujemne. Przyczynia się do tego fakt, że wszystkie krzywe wzorcowe z wyjątkiem krzywej wykreślonej dla benzenu charakteryzują się wysokim wyrazem wolnym. Dlatego też dla gleby B bardzo dobrze sprawdza się pośrednia interpolacyjna strategia wzorcowania względem benzenu. Strategia ta pozwoliła na uzyskanie wyników obarczonych błędem w zakresie od 7,2 do 33,8\%.

Kolejnym etapem doboru odpowiedniej metody wzorcowania było sprawdzenie strategii ekstrapolacyjnej. Podczas tej oceny postępowano analogicznie jak w przypadku węglowodorów benzynowych, czyli dla skażonej wcześniej węglowodorami aromatycznymi gleby wykonano dodatki wzorca zgodnie z wcześniej opisanym schematem.

Wyniki badań przeprowadzonych metodą ekstrapolacyjną przedstawiono w tablicach 5 i 6 .

Wyniki uzyskane dla metody ekstrapolacyjnej na obu poziomach stężeń są zadowalające. Jednak przeciwnie niż w przypadku węglowodorów benzynowych najlepsze wyniki otrzymano przy zastosowaniu dodatków wzorca o stężeniu równym lub mniejszym niż stężenie analitu w badanej próbce.

Tablica 6. Wyniki oznaczania węglowodorów BTEX metodą ekstrapolacyjną $\mathrm{w}$ glebie $\mathrm{F}$

\begin{tabular}{|c|c|c|c|}
\hline & $\begin{array}{l}\text { Symbol } \\
\text { dodatku } \\
\text { wzorca }\end{array}$ & $\begin{array}{l}\text { Wynik oznaczenia } \\
\text { w próbce bez do- } \\
\text { datku wzorca } \\
{[\mathrm{mg} / \mathrm{kg}]}\end{array}$ & $\begin{array}{c}\text { Błąd } \\
\text { względny } \\
{[\%]}\end{array}$ \\
\hline \multirow{4}{*}{$\begin{array}{l}\text { Gleba } F_{0}-\text { benzen } \\
(0,51 \mathrm{mg} / \mathrm{kg})\end{array}$} & $\mathrm{F}_{1}$ & $0,52 \pm 0,13$ & 2,99 \\
\hline & $\mathrm{F}_{2}$ & $0,58 \pm 0,15$ & 13,69 \\
\hline & $\mathrm{F}_{3}$ & $0,88 \pm 0,22$ & 72,60 \\
\hline & $\mathrm{F}_{4}$ & $0,46 \pm 0,12$ & 9,75 \\
\hline \multirow{4}{*}{$\begin{array}{l}\text { Gleba } F_{0}-\text { toluen } \\
(0,82 \mathrm{mg} / \mathrm{kg})\end{array}$} & $\mathrm{F}_{1}$ & $0,80 \pm 0,20$ & 2,22 \\
\hline & $\mathrm{F}_{2}$ & $0,89 \pm 0,22$ & 9,57 \\
\hline & $\mathrm{F}_{3}$ & $1,31 \pm 0,33$ & 60,29 \\
\hline & $\mathrm{F}_{4}$ & $0,69 \pm 0,17$ & 15,28 \\
\hline \multirow{4}{*}{$\begin{array}{l}\text { Gleba } F_{0}-\text { etylobenzen } \\
(0,55 \mathrm{mg} / \mathrm{kg})\end{array}$} & $\mathrm{F}_{1}$ & $0,34 \pm 0,09$ & 37,94 \\
\hline & $\mathrm{F}_{2}$ & $0,44 \pm 0,11$ & 20,46 \\
\hline & $\mathrm{F}_{3}$ & $0,71 \pm 0,18$ & 28,75 \\
\hline & $\mathrm{F}_{4}$ & $0,41 \pm 0,10$ & 25,59 \\
\hline \multirow{4}{*}{$\begin{array}{l}\text { Gleba } F_{0}-\text { ksyleny } \\
(0,48 \mathrm{mg} / \mathrm{kg})\end{array}$} & $\mathrm{F}_{1}$ & $0,56 \pm 0,14$ & 17,17 \\
\hline & $\mathrm{F}_{2}$ & $0,63 \pm 0,16$ & 31,09 \\
\hline & $\mathrm{F}_{3}$ & $0,91 \pm 0,23$ & 89,56 \\
\hline & $\mathrm{F}_{4}$ & $0,60 \pm 0,15$ & 24,54 \\
\hline
\end{tabular}


Analizując wyniki uzyskane dla węglowodorów aromatycznych z grupy BTEX, zauważyć można, że te, które otrzymano przy użyciu metody interpolacyjnej, mogą być obarczone znacznym błędem - sięgającym nawet około $50 \%$, niezależnie od tego, czy dla danego węglowodoru przeprowadzone zostanie wzorcowanie pośrednie, czy bezpośrednie. Wyraźnie widać, że metoda ekstrapolacyjna pozwala uzyskać bardziej poprawne wyniki. Podczas jej realizacji należy pamiętać jednak, że stężenie substancji wzorcowej w dodatku wzorca nie powinno przekraczać ilości odpowiadającej spodziewanej zawarto- ści analitu w badanej próbce. Dlatego też podczas prowadzenia wzorcowania ekstrapolacyjnego należy na wstępie poddać analizie próbkę bez dodatku wzorca i określić w niej poziom zawartości analitów przy użyciu krzywej interpolacyjnej. Wyniki przeprowadzonych badań potwierdziły jednak, że wzorcowanie interpolacyjne dla całej grupy węglowodorów może być prowadzone przy użyciu jednej substancji wzorcowej, stosowanej jako wzorzec pośredni dla pozostałych analitów. Podczas wzorcowania interpolacyjnego pośredniego najlepsze wyniku uzyskano, stosując jako wzorzec pośredni benzen.

\section{Podsumowanie i wnioski}

Niejednorodny charakter próbek stałych skutkuje innym niż w przypadku próbek ciekłych podejściem do analiz pod kątem zawartości węglowodorów ropopochodnych. Próbki stałe, ze względu na trudną matrycę, przysparzają wielu problemów zarówno na etapie ich przygotowania, jak i samej analizy, dlatego też w przypadku pracy z tego typu próbkami niezbędny jest dobór odpowiedniej strategii wzorcowania. Przeprowadzone badania wykazały, że przy oznaczaniu lotnych węglowodorów w próbkach gleby, w zależności od grupy analizowanych związków i zastosowanej metodyki badawczej, odpowiednia może być zarówno strategia interpolacyjna, jak i ekstrapolacyjna. W przypadku węglowodorów benzynowych lepiej sprawdziła się strategia interpolacyjna, dzięki której uzyskano wyniki oznaczania zawartości węglowodorów obarczone błędem względnym nieprzekraczającym $8 \%$ dla próbek o zawartości węglowodorów od 50 do $800 \mathrm{mg} / \mathrm{kg}$. W tym samym zakresie stężeń metoda ekstrapolacyjna pozwoliła na otrzymanie wyników obarczonych błędem sięgającym nawet $90 \%$. Zawężenie zakresu analitycznego (od 50 do
$600 \mathrm{mg} / \mathrm{kg}$ ) oraz precyzyjny dobór stężenia substancji wzorcowej w dodatku wzorca pozwala na uzyskanie również metodą ekstrapolacyjną zadowalających wyników, obarczonych błędem na tym samym poziomie co strategia interpolacyjna. Stosowanie metody ekstrapolacyjnej w przypadku tej grupy węglowodorów wydaje się być jednak niecelowe, ze względu na dużo bardziej skomplikowaną procedurę ekstrapolacyjną w stosunku do interpolacyjnej, przy jednoczesnym braku pozytywnego wpływu na wynik analityczny.

Inaczej przedstawia się sytuacja w przypadku węglowodorów aromatycznych BTEX. Dla tej grupy wyniki uzyskane dzięki strategii interpolacyjnej bezpośredniej obarczone są błędem sięgającym $41 \%$, natomiast otrzymane dzięki strategii interpolacyjnej pośredniej - 44\%. Użycie w tym przypadku strategii ekstrapolacyjnej pozwoliło na poprawę uzyskanych wyników i przy zastosowaniu dodatku wzorca o stężeniu mniejszym lub równym stężeniu analitu w próbce otrzymano wyniki obarczone błędem względnym w zakresie od 0,65 do $38 \%$.

Prosimy cytować jako: Nafta-Gaz 2016, nr 9, s. 736-741, DOI: 10.18668/NG.2016.09.08

Artykuł nadesłano do Redakcji 1.03.2016 r. Zatwierdzono do druku 30.05.2016 r.

Artykuł powstał na podstawie pracy statutowej pt. Optymalizacja strategii wzorcowania wanalizach zawartości węglowodorów ropopochodnych w próbkach stałych - praca INiG - PIB na zlecenie MNiSW; nr zlecenia: 0042/GE/15, nr archiwalny: DK-4100-42/15.

\section{Literatura}

[1] Holewa J., Kusina E., Krasińska A.: Zanieczyszczenia węglowodorowe $w$ zużytych podkładach kolejowych i ich oznaczanie $w$ celu klasyfikacji odpadów. Nafta-Gaz 2008, nr 3, s. 505-211.

[2] Steliga T.: Biodegradacja odpadów wiertniczych zanieczyszczonych substancjami ropopochodnymi. Nafta-Gaz 2009, nr 5, s. 384-391.

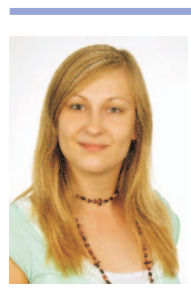

Magdalena WIŚNIECKA

Starszy specjalista badawczo-techniczny w Zakładzie Ochrony Środowiska.

Instytut Nafty i Gazu - Państwowy Instytut Badawczy ul. Lubicz 25 A

31-503 Kraków

E-mail:magdalena.wisniecka@inig.pl

\section{Akty prawne i normatywne}

[3] Rozporządzenie Ministra Środowiska z dnia 9 września 2002 r. w sprawie standardów jakości gleby i standardów jakości ziemi (Dz. U. z 2002 r. nr 165, poz. 1359).

Mgr Jadwiga HOLEWA-RATAJ

Starszy specjalista badawczo-techniczny w Zakładzie Ochrony

Środowiska.

Instytut Nafty i Gazu - Państwowy Instytut Badawczy

ul. Lubicz $25 \mathrm{~A}$

31-503 Kraków

E-mail: jadwiga.holewa@inig.pl 